\begin{tabular}{|cc|}
\hline GASOLINE & VAPOR \\
BENZENE & ALKENES \\
HEXANE & BUTANES \\
POWER SAW & LAWN MOWER \\
ANALYSIS & EXPOSURE \\
\hline
\end{tabular}

Open access accepted manuscript version of

Chemosphere 25 (1992) 763-768

doi:10.1016/0045-6535(92)90066-Z

\title{
Assessment of hydrocarbons in vapours of conventional and alkylate-based petrol
}

\author{
Ulf Östermark and Göran Petersson
}

An analytically related study was previously made for vapor recovery at filling stations 


\title{
ASSESSMENT OF HYDROCARBONS IN VAPOURS OF CONVENTIONAL AND ALKYLATE-BASED PETROL
}

\author{
Ulf Östermark and Göran Petersson \\ Department of Chemical Environmental Science \\ Chalmers University of Technology \\ 41296 Göteborg, Sweden
}

\begin{abstract}
Vapours of recently introduced alkylate-based petrol for power saws, lawn mowers and other petrol-fuelled machines were compared with vapours of conventional petrol varieties. The composition of $\mathrm{C}_{4}-\mathrm{C}_{8}$ hydrocarbons was determined by adsorption sampling and gas chromatography on an aluminium oxide column. Results are given for 22 specific arenes, alkenes and alkanes.

Major advantages of the reformulated petrol with respect to health and environment are the virtual absence of benzene and alkenes in the vapours. The proportions of methylbenzene, hexane and cycloalkanes are also very low. More than $98 \%$ of the vapours are alkanes with a prominent portion of 2,2,4-trimethylpentane and other highly branched $\mathrm{C}_{6}-\mathrm{C}_{8}$ species.
\end{abstract}

\section{INTRODUCTION}

Conventional petrol causes severe hazards to human health and the environment due to hydrocarbons in vapours and a wide range range of air pollutants in exhaust. Presently, strong efforts are made to diminish hazards related to hydrocarbons, by producing reformulated varieties of petrol. Unwanted petrol components are the carcinogenic benzene (Yardly-Jones, 1991) and the specifically neurotoxic hexane (Perbellini et al., 1978). The $\mathrm{C}_{4}-\mathrm{C}_{6}$ alkenes are unwanted because of their rapid conversion to photooxidants (Atkinson, 1990). The alkylation process (Albright, 1990) is presently of great interest because it produces petrol with a low content of all these hydrocarbons.

In Scandinavia, alkylate-based petrol has been introduced for working machines such as power saws and lawn mowers. These applications are important with respect to both high emissions and high exposure levels. The purpose of this study is to compare the hydrocarbon content in vapours of conventional petrol and commercial alkylate-based petrol. 


\section{EXPERIMENTAL}

\section{Investigated fuels}

Conventional petrol (RON 95, unleaded) was collected from pumps at petrol stations in Göteborg of the OK, BP, Shell, Q8 and Statoil marketing chains.

Alkylate-based petrol, marketed by Aspen Petroleum and OK Petroleum, was bought in 51 plastic vessels in retail stores. Both makes were sold for four-stroke engines (Aspen 4T, OK Special) and with $2 \%$ lubrication oil added for two-stroke engines (Aspen 2T, TT Special). Both companies also claim similar specifications; e. g. RON $>95$, MON $>90$, RVP $<60 \mathrm{kPa}, \mathrm{Pb}<$ $0.002 \mathrm{~g} / \mathrm{l}, \mathrm{S}<0.005 \%$, benzene $<0.1 \%$, and no added oxygenates.

\section{Sampling of vapours}

The sampling procedure was arranged so as to simulate emissions and exposure during refuelling of a lawn mower or similar machine. Petrol was poured from the half-filled 51 storage vessel through a funnel into a $750 \mathrm{ml}$ polyethylene tank which was filled up. The tank, prefilled with $50 \mathrm{ml}$ of petrol, and the storage vessel were preconditioned indoors overnight at $19^{\circ} \mathrm{C}$. The time spent for the outdoor refuelling was $\sim 1 \mathrm{~min}$ and equalled the time of sampling.

The sampling cartridge was kept in the breathing zone of the refuelling person who was kneeling on the ground. A portable Gilian air pump was used to give accurate sampling volumes in the range of 10-25 ml. The small sampling volumes permitted the use of Tenax adsorption cartridges without significant break-through losses of the volatile butanes. Alternatively, triplelayer cartridges were used, with Tenax + Carbotrap + Carbosieve S-III as adsorbents (Löfgren et al., 1991).

\section{Analytical method}

In the laboratory, the hydrocarbons were thermally desorbed into a cold trap and analysed by gas chromatography with FID, mainly according to a previously described technique (Löfgren et al., 1991). The column was an $\mathrm{Al}_{2} \mathrm{O}_{3}(5 \% \mathrm{KCl})$ PLOT capillary (Chrompack, $50 \mathrm{~m} \times 0.32 \mathrm{~mm}$ i.d.). The programmed oven temperature was raised from $30^{\circ} \mathrm{C}$ to $110^{\circ} \mathrm{C}\left(10^{\circ} \mathrm{C} \mathrm{min}^{-1}\right)$, kept at $110^{\circ} \mathrm{C}$ for $14 \mathrm{~min}$, and finally raised from $110^{\circ} \mathrm{C}$ to $200^{\circ} \mathrm{C}\left(4^{\circ} \mathrm{C} \mathrm{min}-1\right)$.

\section{RESULTS}

The results given in Table 1 were chosen to demonstrate the basic differences in hydrocarbon composition between the different varieties of petrol. The $\mathrm{C}_{3}-\mathrm{C}_{8}$ hydrocarbons of petrol vapours favourably suit the analytical range of the $\mathrm{Al}_{2} \mathrm{O}_{3}$ column used for the gas chromatographic determinations. The chromatogram given in Figure 1 illustrates the separation of prominent individual hydrocarbons as well as different structurally related groups of hydrocarbons.

\section{Vapours of conventional petrol}

The first vapour category in Table 1 corresponds to conventional petrol with a prominent 
Table 1. Percent composition of hydrocarbons in vapours from different types of petrol ${ }^{\mathrm{a}}$

\begin{tabular}{|c|c|c|c|c|}
\hline \multirow{2}{*}{$\begin{array}{l}\text { Petrol } \\
\text { Basic character }\end{array}$} & \multicolumn{2}{|c|}{ Conventional } & \multicolumn{2}{|c|}{ Reformulated } \\
\hline & Cracked, FCC" & "Reformate" & "Alkylate" & "Alkylate" \\
\hline Marketed grade & Statoil $95^{\mathrm{b}}$ & Shell 95 ${ }^{\mathrm{b}}$ & Aspen $2 \mathrm{~T}^{\mathrm{c}}$ & OK Special ${ }^{c}$ \\
\hline Date of sampling & $10 / 16-91$ & $11 / 15-91$ & $11 / 19-91$ & $11 / 26-91$ \\
\hline Conc. of $\mathrm{CH}_{\mathrm{X}}\left(\mathrm{mg} \mathrm{m}^{-3}\right)$ & 121 & 35 & 61 & 181 \\
\hline Arenes & 2.6 & 9.1 & 1.0 & 0.3 \\
\hline $\begin{array}{l}\text { benzene } \\
\text { methylbenzene }\end{array}$ & $\begin{array}{l}0.8 \\
1.4\end{array}$ & $\begin{array}{l}3.2 \\
4.1\end{array}$ & $\begin{array}{l}0.3 \\
0.5\end{array}$ & $\begin{array}{l}0.07 \\
0.17\end{array}$ \\
\hline Alkenes & 15.8 & 1.3 & 0.4 & 0.5 \\
\hline $\begin{array}{l}\text { C4 } \\
\text { trans-2-butene } \\
\text { 1-butene } \\
\text { methylpropene } \\
\text { cis-2-butene }\end{array}$ & $\begin{array}{l}8.2 \\
2.6 \\
2.0 \\
1.7 \\
1.9\end{array}$ & $\begin{array}{l}0.6 \\
0.19 \\
0.14 \\
0.18 \\
0.15\end{array}$ & $\begin{array}{l}0.3 \\
0.04 \\
0.02 \\
0.18 \\
0.02\end{array}$ & $\begin{array}{l}0.3 \\
0.04 \\
0.06 \\
0.17 \\
0.02\end{array}$ \\
\hline $\begin{array}{l}\text { C5 } \\
\text { trans-2-pentene } \\
\text { 2-methyl-2-butene } \\
\text { 1-pentene } \\
\text { 2-methyl-1-butene } \\
\text { cis-2-pentene }\end{array}$ & $\begin{array}{l}5.7 \\
1.1 \\
1.7 \\
0.6 \\
1.2 \\
0.6\end{array}$ & $\begin{array}{l}0.5 \\
0.09 \\
0.16 \\
0.05 \\
0.08 \\
0.05\end{array}$ & $\begin{array}{l}0.1 \\
0.02 \\
0.03 \\
0.01 \\
0.01 \\
0.01\end{array}$ & $\begin{array}{l}0.1 \\
0.02 \\
0.05 \\
0.02 \\
0.03 \\
0.01\end{array}$ \\
\hline C6 & 1.7 & 0.16 & 0.02 & 0.03 \\
\hline Alkanes & 81.3 & 89.2 & 98.3 & 98.6 \\
\hline $\begin{array}{l}C 4 \\
\text { methylpropane } \\
\text { butane }\end{array}$ & $\begin{array}{l}41.0 \\
16.4 \\
24.6\end{array}$ & $\begin{array}{l}38.5 \\
15.6 \\
22.9\end{array}$ & $\begin{array}{l}54.5 \\
12.3 \\
42.2\end{array}$ & $\begin{array}{r}28.5 \\
4.7 \\
24.0\end{array}$ \\
\hline $\begin{array}{l}C 5 \\
\text { methylbutane } \\
\text { pentane }\end{array}$ & $\begin{array}{r}28.2 \\
23.0 \\
4.6\end{array}$ & $\begin{array}{r}33.9 \\
26.6 \\
6.4\end{array}$ & $\begin{array}{r}20.4 \\
18.9 \\
1.3\end{array}$ & $\begin{array}{r}46.0 \\
44.8 \\
0.9\end{array}$ \\
\hline $\begin{array}{l}\text { C6 } \\
\text { methylcyclopentane } \\
\text { 2,3-dimethylbutane } \\
\text { 2-methylpentane } \\
\text { 3-methylpentane } \\
\text { hexane }\end{array}$ & $\begin{array}{l}8.7 \\
2.2 \\
0.6 \\
3.1 \\
1.7 \\
0.8\end{array}$ & $\begin{array}{r}12.5 \\
2.6 \\
0.1 \\
4.5 \\
3.2 \\
1.8\end{array}$ & $\begin{array}{l}3.7 \\
0.2 \\
1.6 \\
1.0 \\
0.5 \\
0.15\end{array}$ & $\begin{array}{l}2.8 \\
0.04 \\
1.6 \\
0.7 \\
0.3 \\
0.04\end{array}$ \\
\hline${ }^{C 7}$ 2,4-dimethylpentane & $\begin{array}{l}1.6 \\
0.2\end{array}$ & $\begin{array}{l}1.8 \\
0.1\end{array}$ & $\begin{array}{l}2.9 \\
1.3\end{array}$ & $\begin{array}{l}1.5 \\
0.9\end{array}$ \\
\hline$C 8_{2,2,4-\text { trimethylpentane }}$ & $\begin{array}{l}0.8 \\
0.5\end{array}$ & $\begin{array}{l}0.2 \\
0.06\end{array}$ & $\begin{array}{l}16.5 \\
11.0\end{array}$ & $\begin{array}{l}19.1 \\
12.4\end{array}$ \\
\hline
\end{tabular}

\footnotetext{
a Vapour samples taken so as to simulate exposure during refuelling of a lawn mower. Concentrations of specific hydrocarbons are obtained as fractions of the total concentrations given in the column headings.

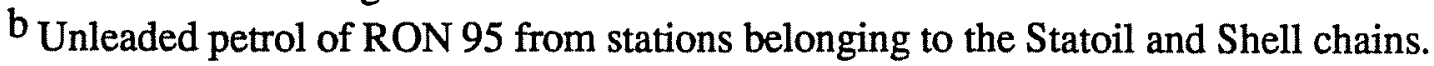

$\mathrm{c}_{\text {From commercial }} 51$ vessels.
} 


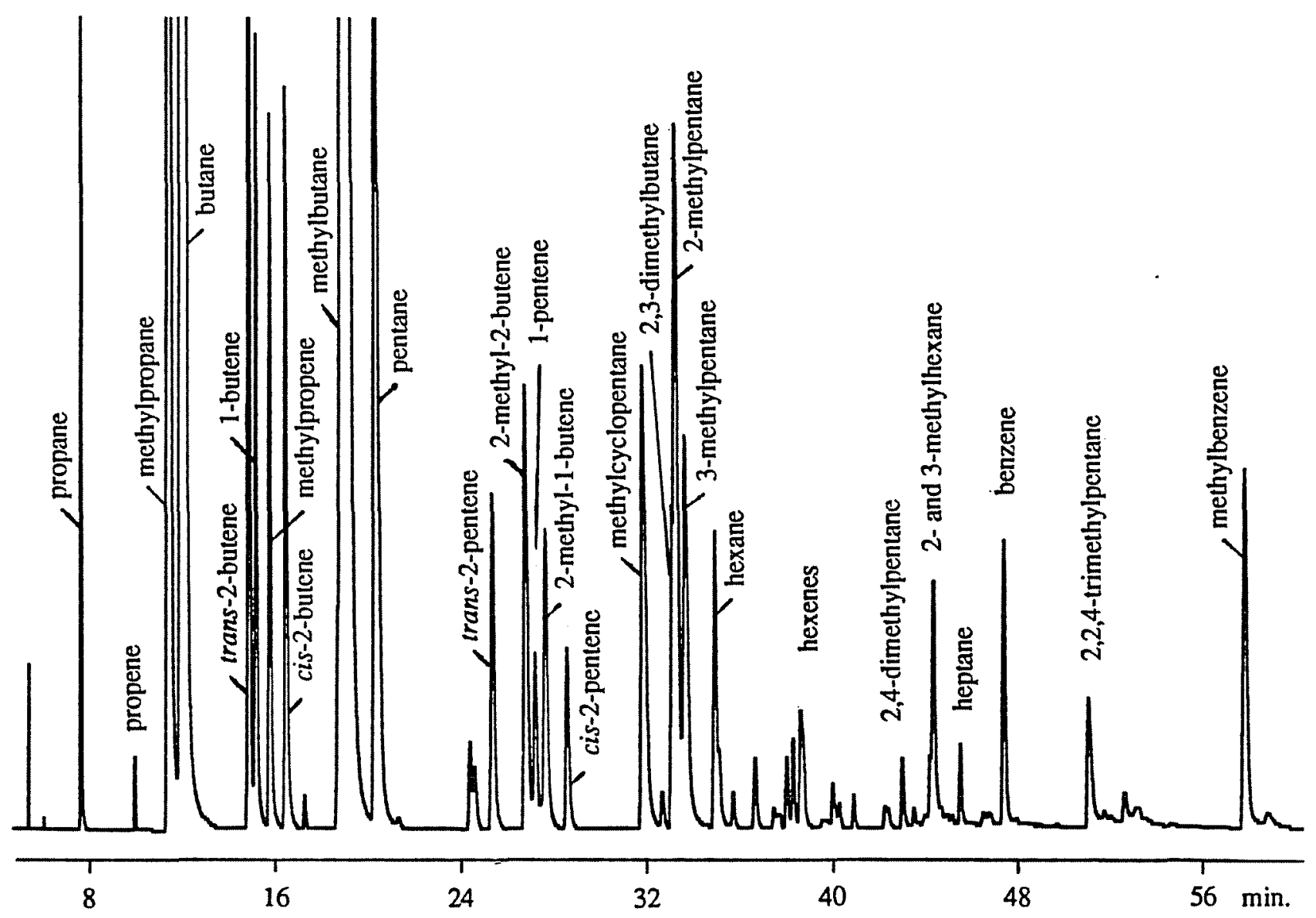

Figure 1. Gas chromatographic separation of vapour hydrocarbons inhaled during refuelling with conventional petrol (Statoil, unleaded RON 95, cf. Table 1).

portion of volatile butenes and pentenes from fluid catalytic cracking (FCC). The proportions between specific alkenes and other hydrocarbons are similar to those reported for vapours from refuelling of cars at petrol stations (Berglund and Petersson, 1990). The proportions are also similar to those reported for certain hydrocarbons in U.S. studies of vapour composition (Scheff et al., 1989). Considering the extensive use of FCC, it is concluded that the composition given is fairly close to an international average for petrol vapour from refuelling.

The second vapour category in Table 1 corresponds to non-FCC petrol with a content of almost $50 \%$ arenes (aromatic hydrocarbons) originating from refineries relying heavily on the catalytic reforming process. The high proportions of the moderately volatile benzene and methylbenzene in the vapour reflect their high proportions in the liquid petrol. The content of alkenes is very low, whereas the content of alkanes is similar to that of the first category of petrol vapour. The composition of vapour from conventional petrol distributed by other marketing chains was found to be intermediate, partly as a result of buying and selling between different companies. Highreformate petrol occurs in limited European regions.

\section{Vapours of alkylate-based petrol}

The last two columns in Table 1 give results for vapour samples of reformulated, alkylate-based petrol. Varieties for two-stroke and four-stroke engines and petrol bought from different retail stores gave similarly composed vapours. Both companies market their products referring to advantages to human health and the environment. 
The proportions of benzene and other arenes are much lower than for conventional petrol. For the OK varieties, the total content of arenes in the petrol is specified to less than $0.5 \%$. Certain Aspen varieties, like Aspen 2T, contain a few per cent of the comparatively non-volatile $\mathrm{C}_{8}$ and higher arenes. From the results of this study, it is concluded that proportions in vapours as low as $0.1 \%$ for benzene, $0.2 \%$ for methylbenzene, and $0.3 \%$ for total arenes can be achieved in practice, although the vapour pressure is kept lower than that of conventional petrol.

The proportion of alkenes is remarkably low compared to conventional petrol with its content of alkenes from catalytic cracking. The comparatively high proportion of methylpropene is probably explained by its presence as a major reactant in the alkylation process. The results demonstrate that the total content of alkenes in vapours may be kept below $0.5 \%$ for commercial alkylate-based petrol.

Methylpropane, butane and methylbutane are major vapour components for the alkylate-based as well as the conventional petrol varieties. The proportions vary according to factors such as permitted or desired volatility, addition of methylbutane (isomerate), and losses of volatiles during storing and handling of petrol.

The predominant characteristic hydrocarbon of alkylates is 2,2,4-trimethylpentane. Although not particulary volatile (b.p. $99^{\circ} \mathrm{C}$ ), it is a major component of the vapours as well. Other prominent $\mathrm{C}_{6}-\mathrm{C}_{8}$ alkanes in the alkylate are also highly branched as a result of the reactions during the alkylation process (Albright, 1990). The remaining $\mathrm{C}_{8}$ alkanes are mainly other trimethylpentanes and dimethylhexanes. The major $C_{6}$ alkane in the vapours is 2,3-dimethylbutane, and the two most prominent $\mathrm{C}_{7}$ alkanes are 2,4-dimethylpentane followed by 2,3-dimethylpentane. This is very different from conventional petrol with 2- and 3-monomethylalkanes as the main constituents and with higher proportions of the unbranched isomers. Another significant difference is the low proportion of methylcyclopentane and other cycloalkanes in alkylate-based petrol.

\section{DISCUSSION}

\section{Human exposure}

The sampling procedure was designed so as to simulate exposure to vapours during refuelling of working machines. The exposure level recorded for separate samples may vary with air motions, but several samples indicated levels of the order of $50 \mathrm{mg} \mathrm{CH}_{\mathrm{x}} \mathrm{m}^{-3}$ for the Aspen alkylate-based petrol, kept at $19^{\circ} \mathrm{C}$. Exposure levels for specific hydrocarbons may be derived from Table 1.

The remarkably low content of benzene in the vapours is an outstanding advantage with respect to health. The exposure to benzene is also decreased by its lower proportion in unburnt fuel emitted with exhaust from the motors. Furthermore, the low content of alkylbenzenes significantly lowers the formation of benzene by incomplete combustion (Neligan et al., 1961). Very low exposure levels for hexane, total arenes and total alkenes are other important advantages of the alkylatebased petrol. 


\section{Photooxidant formation}

With respect to photooxidants, an outstanding feature of the alkylate vapours is their extremely low content of alkenes. Several of the $\mathrm{C}_{4}-\mathrm{C}_{6}$ alkenes react very rapidly not only with the $\mathrm{OH}$ radical but also with ozone (Atkinson, 1990) and contribute efficiently to local as well as regional photooxidant occurrence. The low content of alkenes and alkylbenzenes is also important with respect to exhaust emissions of unburnt reactive hydrocarbons. Relative to petrol consumption, these emissions are largest for small two-stroke engines (outboard motors, mopeds, power saws etc.).

The vapour emissions increase with ambient temperature and are large in the critical photooxidant season during late spring and summer. Consequently, the alkylate-based petrol should be particularly essential for motor boats, lawn mowers and other machines which are used mainly during this season.

\section{Technical aspects on alkylates}

Since its commercial introduction in Sweden in 1989, the marketed volume of alkylate-based petrol has increased to approximately $10000 \mathrm{~m}^{3}$ in 1991 . It has taken approximately $90 \%$ of the market for power saws in forestry and is much appreciated by the heavily exposed forest workers.

The low content of alkenes is advantageous to most petrol-fuelled motors. The high content of 2,2,4-trimethylpentane (RON 100 by definition) gives a beneficially high octane number. Alkylates are therefore often added to motor fuels for cars. The refinery capacity for alkylates is still low in Europe compared to the United States (Albright, 1990) but permits a strongly expanded use of alkylate-based petrol for critical purposes.

\section{REFERENCES}

Albright L. F. (1990). Alkylation will be key process in reformulated gasoline era. Oil Gas J. $\underline{88}$ (46), 79-92.

Atkinson R. (1990). Gas-phase tropospheric chemistry of organic compounds: A review.

Berglund P. M. and Petersson G. (1990). Hazardous petrol hydrocarbons from refuelling with and without vapour recovery. Sci. Total Environ. 91, 49-57.

Löfgren L., Berglund P. M., Nordlinder R., Petersson G. and Ramnäs O. (1991). Selective assessment of $\mathrm{C}_{2}-\mathrm{C}_{6}$ alkenes in air by adsorption sampling and gas chromatography. Int. $J$. Environ. Anal. Chem. 45, 39-44.

Neligan R. E., Mader P. P. and Chambers L. A. (1961). Exhaust composition in relation to fuel composition. JAPCA 11, 178-186.

Perbellini L., Brugnone F. and Pavan I. (1980). Identification of the metabolites of n-hexane, cyclohexane, and their isomers in men's urine. Toxicol. Appl. Pharmacol. 53, 220-229.

Scheff P. A., Wadden R. A., Bates B. A. and Aronian P. F. (1989). Source fingerprints for receptor modeling of volatile organics. JAPCA $39,469-478$.

Yardley-Jones A., Anderson D. and Parke D. V. (1991). The toxicity of benzene and its metabolism and molecular pathology in human risk assessment. Br. J. Ind. Med.48, 437-444. 